\title{
Penerapan Metode User Centered Design (UCD) dalam Pembangunan Layanan Online Jual Beli Barang Bekas
}

\author{
Bonifasius Adhi Pratama ${ }^{1}$, Umi Proboyekti ${ }^{2}$, Katon Wijana ${ }^{3}$ \\ Sistem Informasi, Universitas Kristen Duta Wacana \\ Jl. Dr. Wahidin Sudirohusodo No. 5-25, Yogyakarta \\ ${ }^{1}$ bonifasius.adhi@si.ukdw.ac.id \\ 2othiedstaff.ukdw.ac.id \\ ${ }^{3}$ katony@staff.udkw.ac.id
}

\begin{abstract}
Every year many students migrate from various regions in Indonesia to Yogyakarta to continue their education, at the same time there are also some who have graduated. Some who have graduated choose to return to their home regions or work outside the city. New students who come abroad usually choose boarding houses and need boarding furnitures. At the same time, students who have graduated need a place to accommodate the boarding furnitures because it is not possible to bring all the furnitures. From these problems, the writer makes a website application for buying and selling used boarding goods with the aim to help connect sellers and buyers who need used boarding furnitures that can sell individually, in packages, or transacting by barter. The website application for buying and selling used boarding furniture was prepared using the User Center Design (UCD) method. The subjects of this study were students, and people who were living in a boarding house in the city of Yogyakarta. The last process is testing using usability testing. There were 22 respondents involved in this test. The final results of the research conducted an average of $93 \%$ for members as buyers and 92\% for members as sellers. The conclusion from these results shows that the site that was built was usable.
\end{abstract}

Intisari - Setiap tahun banyak mahasiswa merantau dari berbagai daerah di Indonesia ke Yogyakarta untuk melanjutkan pendidikan, diwaktu yang sama ada pula yang telah lulus. Sebagian yang telah lulus memilih untuk kembali ke daerah asalnya atau bekerja di luar kota. Mahasiswa baru yang datang merantau biasa memilih kos sebagai tempat tinggal dan membutuhkan perabotan kos. Diwaktu yang sama, mahasiswa yang telah lulus membutuhkan tempat untuk menampung perabotan kosnya karena tidak mungkin dibawa semua perabotannya. Dari permasalahan tersebut penulis membuat aplikasi website jual beli barang bekas kos, dengan tujuan untuk membantu menghubungkan penjual dan pembeli yang membutuhkan perabotan kos bekas yang dapat menjual secara satuan, sepaket, atau bertransaksi dengan cara barter. Aplikasi website jual beli perabotan kos bekas ini disusun dengan menggunakan metode User Center Design (UCD). Subjek dari penelitian ini adalah mahasiswa, dan orang umum yang sedang kos di kota Yogyakarta. Proses terakhir yaitu melakukan pengujian dengan menggunakan usability testing. Responden yang terlibat dalam pengujian ini berjumlah 22 orang. Hasil akhir dari penelitian yang dilakukan mendapat rata-rata $93 \%$ untuk member sebagai pembeli dan $\mathbf{9 2 \%}$ untuk member sebagai penjual. Kesimpulan dari hasil tersebut menunjukkan bahwa wesbite yang telah dibangun sudah usable.

Kata Kunci- Jual Beli Online, User Centered Design, Barter

\section{Pendahuluan}

Kota Yogyakarta merupakan kota yang dikenal sebagai kota pelajar. Jumlah perguruan tinggi yang terdata pada kopertis wilayah V D.I. Yogyakarta berjumlah 107 [1]. Setiap tahun banyak mahasiswa merantau dari berbagai macam daerah yang ada di Indonesia. Ada mahasiswa yang datang ada pula mahasiswa yang telah lulus. Sebagian mahasiswa yang sudah lulus memilih untuk kembali ke daerah asalnya atau bekerja di luar kota Yogyakarta, artinya mahasiswa yang telah lulus tersebut akan meninggalkan tempat tinggal atau kos yang mereka tempati selama kuliah di Yogyakarta. Mahasiswa yang telah lulus tersebut merasa bingung dengan apa yang harus dilakukan pada barangbarang perabotan kos yang sudah tidak terpakai, karena tidak semua barang dapat mereka bawa. Barang-barang seperti meja, lemari pakaian, rak buku, ember, galon adalah barangbarang yang biasanya mereka tinggalkan. Waktu yang sama setiap tahun kota Yogyakarta kedatangan mahasiswa baru yang akan kuliah di Yogyakarta. Para mahasiswa baru tersebut tentu tidak datang dengan membawa perabotan kos dan perlu memenuhi kebutuhan perabotan kos mereka masing-masing yang sebagian besar berasal dari luar daerah dan memilih kos sebagai tempat tinggalnya.

Sebagai mahasiswa baru dalam memenuhi kebutuhan barang-barang perabotan kosnya, cenderung lebih banyak yang membeli secara langsung di toko dan dalam kondisi baru karena lebih cepat dan banyak yang menjual di berbagai tempat seperti swalayan yang menyediakan perabotan kos. Alasan tidak membeli barang bekas karena sebagai warga

Pendatang baru masih belum tahu tempat-tempat yang menjual perabotan kos bekas. Padahal bila membeli perabotan kos bekas layak pakai, dapat menghemat pengeluaran. Bagi mereka tidak semua perabotan dapat dibeli dengan kondisi bekas, untuk alat-alat makan kebanyakan suka membeli baru atau bawa sendiri dari rumah, selain itu juga untuk barang elektronik lebih suka membeli baru kerena lebih terjamin kualitasnya. Bagi mereka saat pertama kali akan kos, perabotan bekas yang masih layak dibeli dalam kondisi bekas antara lain seperti meja, kursi, galon, lemari buka, lemari pakaian, kipas angin, dispenser, dan cermin.

Dari hasil wawancara bila nantinya mereka telah lulus barang-barang yang mereka tinggalkan lebih tertarik untuk untuk ditinggal di kos saja atau dijual kembali karena lebih efektif daripada harus dibawa pulang atau dibuang. Dari 
semua cara yang dapat dilakukan dalam menjual barang bekas secara online, penulis mengusulkan marketplace yang dapat mempertemukan penjual dan pembeli yang secara khusus menjual barang-barang bekas perabotan kos. Adapun marketplace yang akan dibuat untuk memberikan alternatif lain dalam menjual dan membeli barang bekas perabotan kos seperti dapat membeli menjual secara satuan, dalam bentuk paket atau dengan cara bertukar (barter).

\section{II.LANDASAN TEORI}

\section{A.User Centered Design}

User Centered Design adalah suatu metode yang menjelaskan proses desain dimana pengguna akhir mempengaruhi bagaimana suatu desain terbentuk [2]. User Centerd Design berfokus berdasarkan desain yang berpusat pada manusia dengan analisis target pengguna yang lebih mendalam. User Centered Design memperhatikan detail tentang target pengguna yang menjadi obejek desain, seperti memperhitungkan usia, jenis kelamin, tingkat pendidikan potensial, latar belakang profesional, environment pengguna produk, ciri emosional dan persepsi fisik serta tingkat kesadaran teknologi dan faktor-faktor lainnya. Hal ini tidak hanya berkonsentrasi pada karakteristik dan persepsi manusia secara umum namun juga sifat dan fitur spesifik dari target pengguna.

Teknik yang dipakai dalam pengumpulan data dengan metode UCD adalah :

1. Wawancara, mengajukan pertanyaan-pertanyaan langsung kepada calon pengguna mengenai segala kebutuhan yang diperlukan pada sistem yang akan dibangun.

2. Observasi, mengamati secara langsung pada calon pengguna mengenai kebiasaan menggunakan website jual beli online.

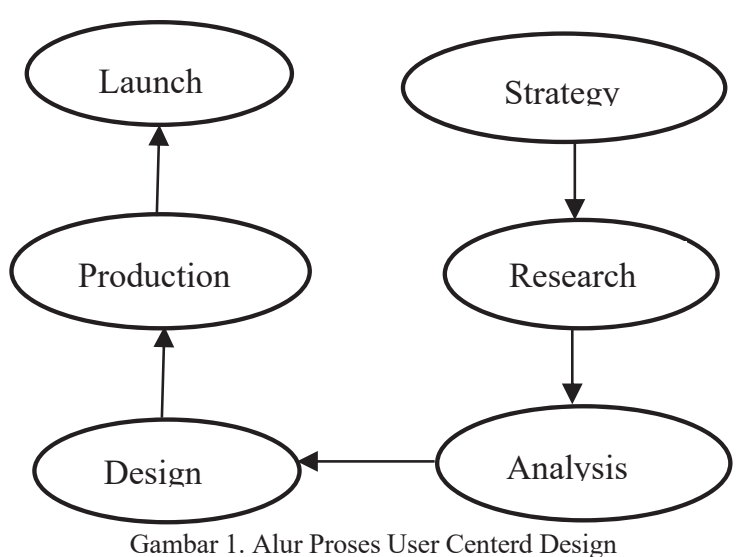

Proses dari setiap tahap aktivitas UCD mungkin saja berbeda dalam setiap perusahaan atau agensi. Mereka juga dapat membuat kesepakatan untuk tahap tambahan di antara tahap analysis dan design. Secara umum proses UCD adalah [3] :

1. Strategy, memiliki visi jangka panjang dari sebuah organisasi. Strategi yang mendasari akan membentuk tujuan, apa yang diharapkan, bagaimana ukuran keberhasilannya dan prioritas apa yang seharusnya dilakukan.
2. Research, melakukan aktivitas dengan pengguna bisa dilakukan dengan wawancara.

3. Analysis, tujuan dari tahap ini adalah untuk menarik wawasan dari data yang dikumpulkan selama tahap research. Pada aktivitas ini, UX designer juga mengkomunikasikan pemahaman mereka kepada end-user untuk membantu mengkonfirmasi valid atau tidaknya asumsi apa pun yang dibuat.

4. Design pada tahap ini UX designer meminta masukan atau timbal balik dari pengguna mengenai ide-ide yang dirancang untuk diperbaiki secara lebih baik lagi sesuai kebutuhan pengguna.

5. Production, tahap ini adalah tahap akhir yaitu melakukan pembuatan aplikasi setelah melewati tahap-tahap sebelumnya.

\section{B. Usability Testing}

Definisi usability adalah menilai seberapa mudah antarmuka pengguna digunakan [4]. Kata usability mengacu pada metode untuk meningkatkan kemudahan penggunaan selama proses desain. Berdasarkan definisi tersebut usability diukur berdasarkan komponen :

1. Kemudahan (learnability) didefinisikan seberapa cepat pengguna mahir dalam menggunakan sistem serta kemudahan dalam penggunaan menjalankan suatu fungsi serta apa yang pengguna inginkan dapat meraka dapatkan

2. Efisiensi (efficiency) didefinisikan sebagai sumber daya yang dikeluarkan guna mencapai ketepatan dan kelengkapan tujuan.

3. Mudah diingat (memorability) didefinisikan bagaimana kemampuan pengguna mempertahankan pengetahuannya setelah jangka waktu tertentu, kemampuan mengingat didapatkan dari peletakkan menu yang selalu tetap.

4. Kesalahan dan keamanan (errors) didefinisikan berapa banyak kesalahankesalahan apa saja yang dibuat pengguna, kesalahan yang dibuat pengguna mencakup ketidaksesuaian apa yang pengguna pikirkan dengan apa yang sebenarnya disajikan oleh sistem.

5. Kepuasan (satisfaction) didefinisikan kebebasan dari ketidaknyamanan, dan sikap positif terhadap penggunaan produk / ukuran subjektif sebagaimana pengguna merasakan tentang penggunaan sistem.

Dalam mengukur usability bergantung pada kemampuan pengguna dalam menggunakan sistem yang telah dibangun. Beberapa parameter yang digunakan adalah:

1. Success rate yaitu mengukur tingkat keberhasilan pengguna dalam menyelesaikan semua tugas yang ada pada web.

2. Error rate, tingkat kesalahan yang dilakukan oleh pengguna pada saat menyelesaikan tugas.

3. User's subjective satisfaction, tingkat kepuasan pengguna dalam penyelesaikan keseluruhan tugas.

Kemudian untuk menghitung tingkat success rate, responden harus menyelesaikan semua tugas dan berapa banyak tugas yang berhasil dikerjakan akan digunakan dalam menentukan persentase keberhasilan. Cara menghitungnya dapat menggunakan rumus sebagai berikut dengan kondisi misalnya task berjumlah 15 dan responden berhasil menyelesaikan 7 . 
Responden $(\mathrm{i})=$ Task Completed $(0 \mathrm{f} 15): 7 / 15 \times 100 \%=47 \%$

Kemudian untuk menghitung tingkat error rate dengan cara mencatat berapa kali responden melakukan kesalahan dalam menyelesaikan tugas. Cara menghitungnya adalah pertama yang dilakukan mendapatkan jumlah error minimal dan maksimal dari semua responden, kemudian masukkan kedalam rumus sebagai berikut :

Responden $(i)=(1-$ jumlah error responden $(i) /$ jumlah error $\max )) * 100 \%$

Kemudian untuk menghitung user's subjective satisfaction dengan cara menentukan terlebih dahulu rating maksimalnya. Misalnya rating maksimalnya 6 kita masukkan kedalam rumus :

$$
\text { (Rating/6)*100\% }
$$

\section{Barter}

Perkembangan alat tukar di Indonesia diawali dengan adanya sistem barter. Barter adalah suatu perjanjian dimana kedua belah pihak mengikat dirinya untuk saling memberikan suatu barang secara timbal balik sebagai gantinya barang yang lain [5]. Manusia membutuhkan sistem barter karena pada dasarnya manusia tidak dapat memenuhi kebutuhan barang untuk hidupnya sendiri, oleh karena itu manusia membutuhkan sistem barter untuk memperoleh barang yang dibutuhkan. Barter juga dapat diartikan sebagai tukar menukar barang satu dengan barang yang lain. Kelemahan barter ialah sulitnya dalam mencari orang yang sama-sama membutuhkan barang dalam satu waktu. Beberapa jenis barter dan syarat-syarat yang harus ada pada saat akan melakukan transaksi dengan cara barter yaitu [6] :

a. Jenis - jenis barter

1. Barter langsung, merupakan pertukaran secara langsung

2. Barter alih, merupakan barter bila di salah satu negara yang sedang melakukan barter tidak bisa memanfaatkan barang hasil barternya sampai mengalihkan barang itu ke negara lain.

3. Barter timbal beli, merupakan barter karena adanya kerjasama untuk saling membeli barang atau jasa yang dibutuhkan satu sama lain.

4.

b. Syarat-syarat barter

1. Orang yang akan melakukan pertukaran harus saling mempunyai barang untuk ditukarkan.

2. Orang yang akan melakukan pertukaran harus saling membutuhkan barang yang akan ditukarkan serta harus dilakukan pada waktu yang sama.

3. Barang yang ditukarkan harus memiliki nilai yang sama, minimal mendekati kesamaan.

\section{D.E-Commerce}

Sebagai pelaku bisnis dalam mengikuti arus perkembangan dunia digital sangat diperlukan untuk memenangkan persaingan. Kemajuan teknologi menuntut setiap pelaku bisnis mengembangkan cara mereka dalam berjualan. Kondisi ini menjadikan pasar perdangan semakin terbuka tanpa batas dan peluang yang setara bagi pelaku bisnis tidak mengenal dari perusahaan besar, menengah, atau kecil. Salah satunya dengan memanfaatkan internet. Internet memiliki dampak besar terhadap semua aspek kehidupan dan telah berkembang menjadi alat yang tangguh. Saat ini semua orang terlibat dalam revolusi yang terjadi dalam perdagangan dan telekomunikasi. Ini adalah solusi yang harus dipertimbangkan dan menemukan cara untuk membantu konsumen. E-Commerce atau Perdagangan Elektronik adalah metodologi bisnis modern yang membahas kebutuhan organisasi bisnis, vendor, dan pelanggan untuk mengurangi biaya dan meningkatkan kualitas barang dan jasa sambil meningkatkan kecepatan pengiriman [7].

Proses bisnis yang digunakan dalam kasus jual beli online barang bekas perabotan kos ini customer to customer (C2C). Model bisnis ini di mana pelanggan dapat berdagang satu sama lain biasanya dalam lingkungan online. C2C dilakukan antara konsumen dengan konsumen, yaitu perorangan yang menjual barang atau jasanya melalui situs marketplace atau situs jual beli. Karakteristik dari ECommerce model $\mathrm{C} 2 \mathrm{C}$ ini adalah satu pelanggan membeli barang dari pelanggan lain menggunakan bisnis atau platform pihak ketiga untuk memfasilitasi transaksi. Keuntungan bagi pelanggan adalah mereka mendapat manfaat dari dalam menemukan barang-barang yang sulit ditemukan di tempat lain. Situs $\mathrm{C} 2 \mathrm{C}$ nyaman karena tidak perlu mengunjungi toko secara langsung, konsumen hanya mencantumkan produk mereka secara online dan pembeli datang kepada mereka. Selain itu sistem pembayarannya pun harus menggunakan fasilitas transaksi online atau rekening pihak ketiga untuk menjamin keamanan. Penjual akan menerima uang pembayaran setelah barang diterima oleh pembeli. Selama barang belum sampai, uang akan disimpan di rekening pihak ketiga. Jika transaksi gagal, uang pun akan dikembalikan pada pembeli.

\section{Metode PenElitian}

Metode yang digunakan sebagai langkah-langkah untuk pemecahan masalah dalam penelitian ini adalah sebagai berikut :

\section{A.Observasi}

Selain melakukan wawancara, penulis juga melakukan observasi pada anak kos. Tugas yang diberikan pada saat observasi adalah mencari lemari pakaian bekas pada aplikasi Tokopedia. Objek yang diamati adalah mengenai sifat pada pengguna saat akan berbelanja di toko online, antara lain yang dilakukan pertama saat akan mencari barang. Selain itu juga dilakukan pengamatan pada salah satu forum Facebook jual beli barang bekas mengenai barang yang sering dijual, proses transaksi, dan cara menjual barangnya. Kedua hal tersebut menjadi dasar bagaimana sifat pengguna saat akan berbelanja online.

\section{1) Hal Pertama Dilakukan Saat Belanja Online}

Dalam observasi tersebut terlihat cara pengguna dalam mendapatkan barang yang diinginkan. Rata-rata bila sudah tahu barang yang akan dibeli mereka cenderung langsung mengetik di kolom pencarian karena bisa lebih cepat mendapatkan barang yang dicari. Alasan mereka tidak 
mencari melalui kategori karena jumlah kategori yang banyak sehingga membutuhkan waktu yang lebih lama dibanding lewat kolom pencarian.

\section{2) Pengamatan Pada Forum Jual Beli Barang Bekas Anak Kos Yogyakarta}

Dari observasi pada forum jual beli barang kos pada Facebook, banyak ditemukan orang yang sering menjual barangnya langsung sepaket, misalnya meja, kursi, dan lemari sekaligus. Selain itu juga terdapat orang yang masih melakukan tukar tambah barang. Dari kebiasaan tersebut bisa diterapkan juga sebagai pilihan jenis barang pada pembangunan layanan online jual beli barang bekas, sehingga pengguna dapat menjual barang antara satuan atau langsung sepaket. Selain itu untuk proses transaksi barter atau tukar tambah bisa digunakan sebagai opsi dalam bertransaksi jual beli barang bekas online.

\section{3) Wawancara}

Target calon pengguna sistem yang akan dibangun merupakan kalangan anak kos, seperti mahasiswa baru, mahasiswa yang akan lulus, atau orang umum yang sedang membutuhkan perabotan kos. Rata-rata mahasiswa sudah sering dan mengerti dalam melakukan transaksi online. Saat menggunakan aplikasi jual beli online terkadang tidak hanya untuk membeli barang saja, namun terkadang sekedar melihat-lihat dan mengecek harga.

Untuk melengkapi data dilakukan juga wawancara dan observasi pada calon pengguna. Wawancara dilakukan dengan mengajukan beberapa pertanyaan kepada calon pengguna. Pertanyaan yang diajukan berjumlah 9 berkaitan dengan barang bekas perabotan kos. Contoh pertanyaannya seperti lebih suka barang baru atau bekas beserta alasannya, barang apa saja kebutuhan anak kos, contoh barang yang mau dibeli dalam kondisi bekas, alasan memilih belanja online, pernah kecewa atau tidak belanja online, apa yang akan dilakukan pada barang perabotan kos yang dimiliki saat akan selesai kos, pendapat mengenai barter, fitur atau saran untuk sistem yang akan dibangun.

Wawancara dilakukan kepada 10 orang. Dari hasil wawancara diketahui barang-barang seperti meja, lemari pakaian, kasur, kipas angin, dispenser, cermin, ember merupakan barang-barang yang harus ada saat pertama kali kos. Namun dari semua barang tersebut tidak semuanya suka dengan kondisi bekas, barang yang masih layak bila dibeli dengan kondisi bekas antara lain meja, lemari pakaian, lemari buku, kursi, cermin, galon, kipas angin. Karena sistem ini adalah jual beli barang bekas online, dari hasil tersebut dapat membantu penulis dalam menentukan kategori barang yang akan digunakan. Alasan berbelanja online adalah memperoleh kemudahan, kenyamanan, hemat waktu, dan harga diketahui langsung untuk penyesuaian anggaran. Sedangkan pengalaman dalam berbelanja online dari 10 orang $80 \%$ orang yang pernah kecewa sedangkan yang tidak pernah sebanyak $20 \%$. Saat akan lulus atau selesai kos hal yang dilakukan pada barang-barang perabotan kos adalah sebanyak $40 \%$ barang-barang besar yang sulit dibawa dijual, beberapa dijual dengan menawarkan langsung ke adik tingkat, $30 \%$ diberikan ke teman satu kos yang membutuhkan, 30\% sisanya ditinggal di kos atau dibawa pulang. Selain itu saran atau fitur yang menjadi masukan untuk sistem yang akan dibangun adalah tampilan lebih ringkas, barang ditempatkan sesuai kategorinya, tombol fungsi harus lebih mencolok, foto yang ditampilkan jelas, keamanan transaksi

Berdasarkan hasil wawancara dan observasi yang telah dilakukan, terdapat beberapa daftar kebutuhan pengguna yang nantinya akan diterapkan pada sistem pembangunan layanan online jual beli barang bekas.

\section{a. Tampilan Lebih Ringkas dan Tombol-tombol Fungsi Menonjol \\ Hasil wawancara yang dilakukan kepada anak kos} sering kesulitan menemukan barang yang diinginkan karena tampilan yang begitu ribet dan kategori barang yang begitu banyak. Nantinya desain yang akan diterapkan akan dibuat lebih ringkas dengan menampilkan barang-barang kebutuhan perabotan kos saja sehingga lebih cepat dalam mendapatkan barang yang diinginkan. Selain itu untuk desain tombol-tombol fungsi yang penting akan lebih ditonjolkan dari segi warna,bentuk, dan keterangan sehingga dapat mempermudah dalam penggunaan sistem.

\section{b. Barang Sesuai dengan Kategori}

Pengalaman anak kos dari hasil wawancara dalam mencari barang pada aplikasi online ditemukan bahwa banyak penempatan barang yang tidak sesuai dengan kategorinya, sehingga pengguna mengalami kesulitan dalam mencari barang. Nantinya barang yang paling dibutuhkan akan digunakan sebagai pilihan kategori, sehingga dapat mempercepat pengguna saat akan mencari barang berdasarkan kategori barangnya.

\section{c. Fitur Pencarian}

Dari hasil observasi dalam mencari barang pengguna lebih sering langsung mengetik pada kolom pencarian namun bila tidak ditemukan akan mencari secara manual pada setiap kategori barangnya.

\section{d. Dapat Menjual dan Membeli Barang Satuan atau Sepaket}

Saat akan lulus mahasiswa ingin barangnya cepat terjual dan tanpa ribet, sehingga biasanya menjual langsung secara sepaket misalnya meja, kursi, dan lemari dengan total harga langsung dari ketiga item barang tersebut. Sehingga pada desain website nanti akan ada pilihan jenis barang untuk mempermudah bila akan membeli atau menjual barang secara satuan atau langsung sepaket. 


\section{4) Desain}

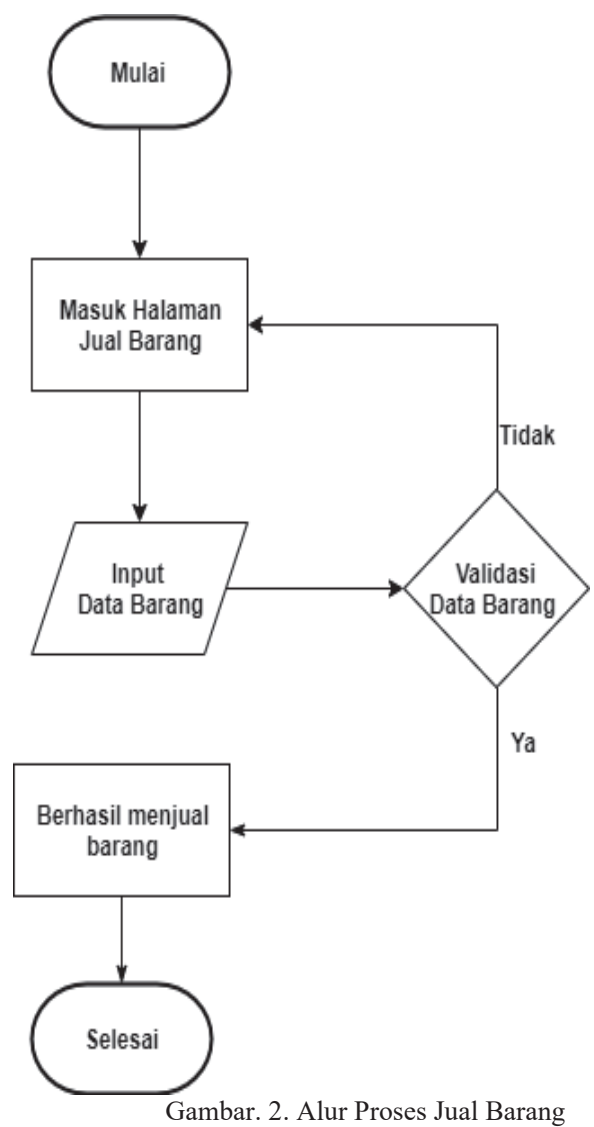

a. Alur Proses Jual Barang

Gambar 2 merupakan alur proses saat akan jual barang. Sebagai pengguna baru yang akan menjual barang, pertama yang harus dilakukan adalah mendaftar sebagai member terlebih dahulu. Setelah mendaftar maka pengguna melakukan login dengan akun yang sudah terdafar.Penjual masuk pada menu akun saya, kemudian pilih jual barang. Pada halaman jual barang, masukkan semua data produk pada kolom yang telah disediakan sesuai dengan informasi produk yang akan dijual. Setelah selesai maka akan menunggu validasi barang yang dilakukan oleh admin sebelum barang tampil pada halaman utama website. Jika admin menerima validasi, maka barang akan langsung tampil pada menu halaman website.

b. Alur Proses Membeli Barang

Sebagai pengguna yang akan membeli barang, pertama yang harus dilakukan adalah mendaftar sebagai member terlebih dahulu, namun jika sudah pernah mendaftar dapat langsung login dengan akun yang sudah dimiliki. Setelah login pilih barang yang akan dibeli dan memasukkan ke dalam keranjang selanjutnya klik tombol checkout untuk melanjutkan pada proses selanjutnya. Pada halaman checkout pengguna diminta memasukkan alamat pengiriman barang. Setelah selesai proses checkout, pembeli diminta untuk mengirimkan bukti transfer. Semua informasi pembelian barang dapat dilihat pada menu pembelian detail transaksi pembeli. Setelah di validasi oleh penjual, barang akan dikirim dan pembeli dapat melihat nomer resi pengiriman pada detail pembelian. Setelah barang sampai, pembeli melakukan validasi bahwa produk telah diterima.

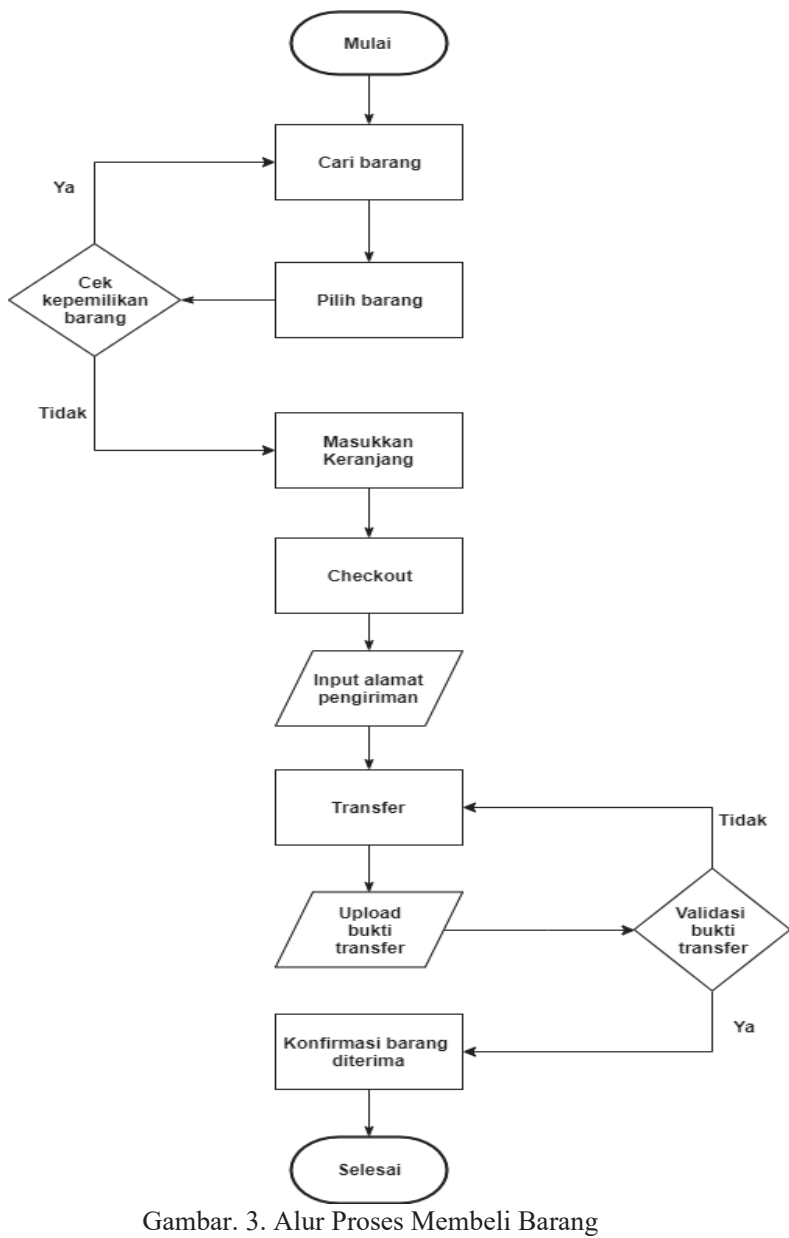

c. Alur Proses Barter

Saat akan melakukan barter, pertama yang dilakukan adalah mencari barang barter yang diinginkan. Setelah itu pilih dan klik tombol barter dan akan masuk pada halaman barter. Pada halaman barter masukkan informasi produk yang akan dibarterkan dengan orang lain. Setelah itu tunggu validasi dari pemiliki barang yang memiliki barang barter tersebut. Pada saat akan melakukan barter pastikan nama barang jelas, nilai barang yang dimiliki tidak berbeda jauh dengan barang yang akan diajak untuk barter. Selain itu pastikan foto barang yang dimiliki terlihat jelas agar pemilik barang barter tertarik untuk setuju melakukan proses transaksi barter. Jika setuju maka sistem akan langsung menampilkan nomer telepon untuk saling bertransaksi lebih lanjut, jika tidak setuju maka status akan transaksi akan berubah menjadi tidak dan nomer telepon tidak akan ditampilkan. 


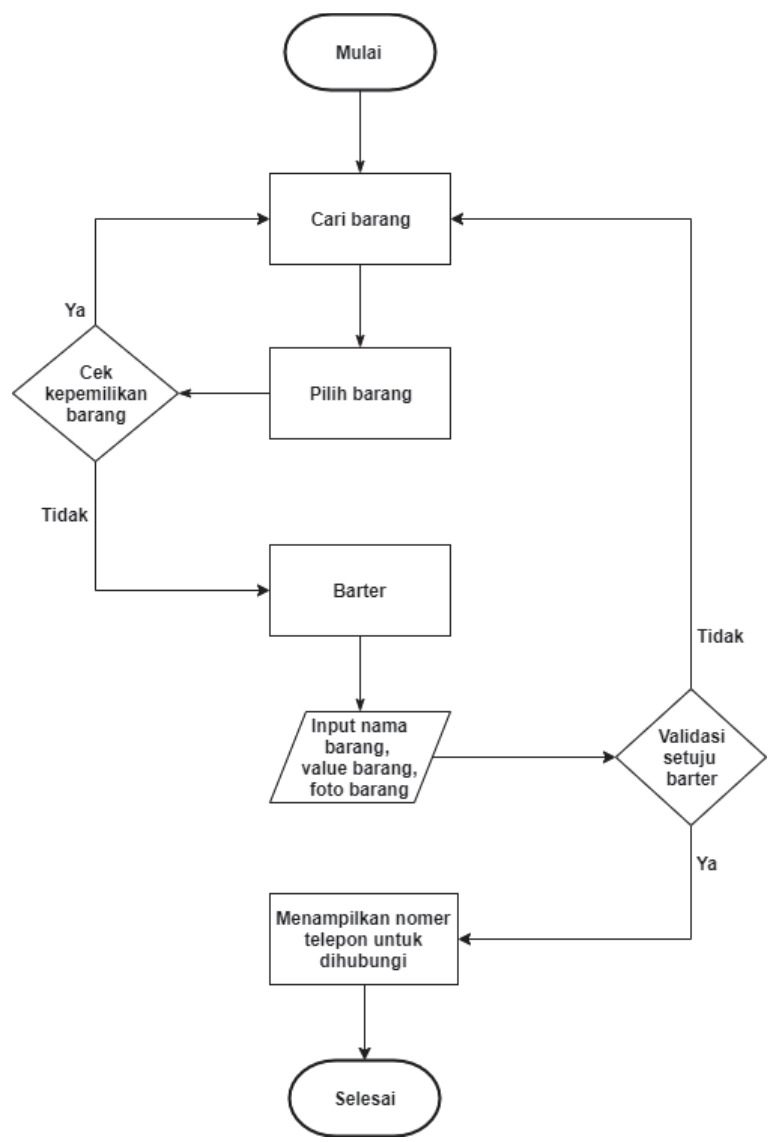

Gambar. 4. Alur Proses Barter

\section{d. Data Flow Diagram (DFD)}

Data flow diagram merupakan suatu alat untuk menggambarkan bagaimana aliran data mengalir. Melalui data flow diagram dapat diketahui darimana data berasal, bentuk masukan, proses yang terjadi, dan bentuk keluaran data.

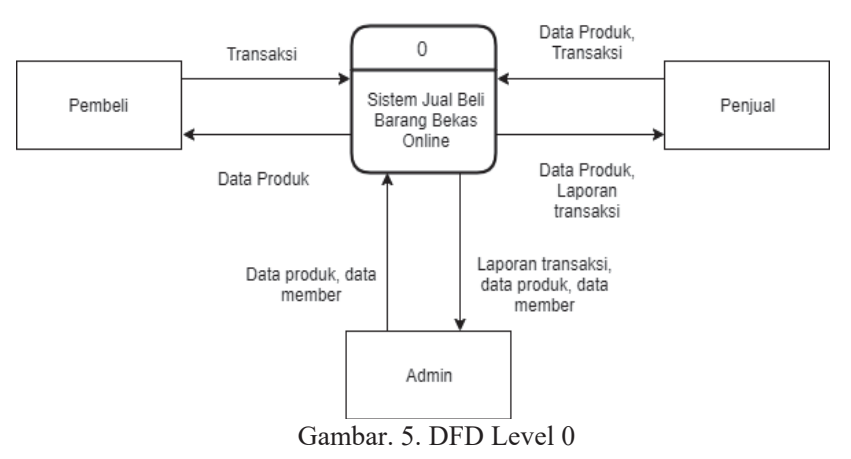

e. Model Data Logika (MDL)

Model data logika merupakan suatu teknik yang menjelaskan struktur proses bisnis dan aturan-aturan sebagai masukan dalam perancangan database. Dalam proses pembuatan model data logika, terbagi menjadi 8 tahap yaitu identifikasi entitas utama, hubungan antar entitas, menentukan kunci primer dan kunci alternatif, menentukan kunci tamu, menentukan kunci aturan bisnis, penambahan atribut bukan kunci, validasi aturan normalisasi, dan menentukan domain.

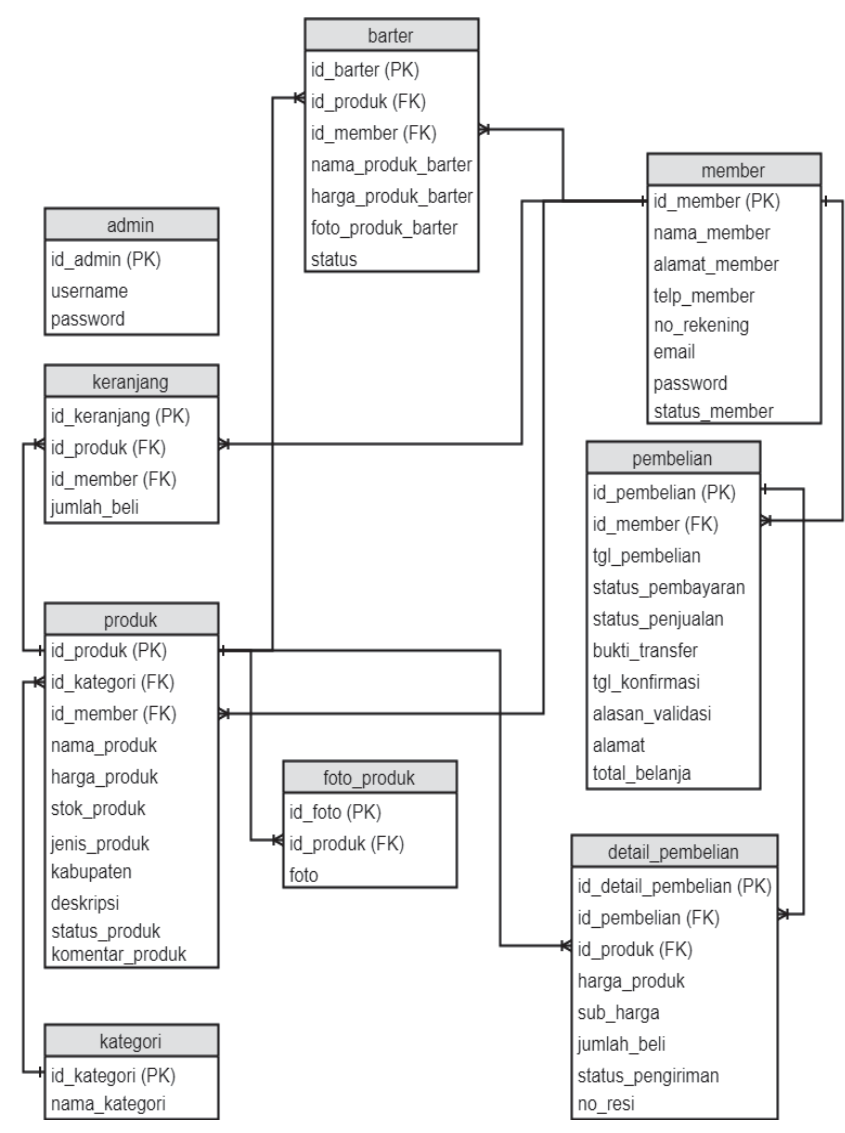

Gambar. 6. Validasi Aturan Normalisasi

\section{HASIL DAN ANALISIS}

\section{A.Implementasi Sistem}

Pada bagian ini akan dijelaskan hasil implementasi dari sistem yang telah dibangun. Sistem jual beli barang bekas online yang telah dibangun akan dilakukan pengujian dengan menggunakan usability test. Pengujian dengan menggunakan 3 parameter yaitu Success rate, Error Rate, dan User's subjective satisfaction. Dari hasil pengujian dengan menggunakan ketiga parameter tersebut, selanjutnya akan dikombinasikan untuk mendapatkan hasil persentase task, accuracy, satisfaction dan analisis dari setiap parameter dan kombinasi.

\section{Jenis Barang}

Pada saat akan melakukan transaksi pembeli dapat memilih jenis barang yang diinginkan. Pembeli dapat membeli barang satuan, sepaket, atau bertransaksi dengan cara barter seperti pada Gambar 7.

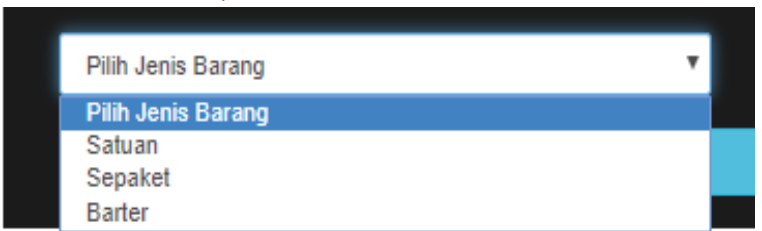

Gambar. 7. Jenis Barang 


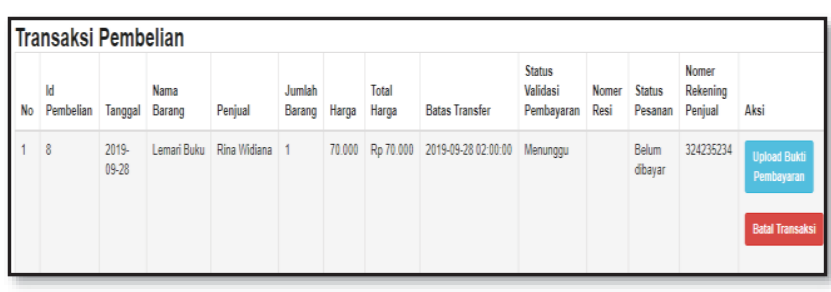

Gambar. 8. Detail Transaksi

2. Transaksi

Gambar 8 merupakan tampilan dari halaman detail transaksi. Semua informasi pembelian dapat dilihat pada menu pembelian. Untuk transaksi barter dapat dilihat pada Gambar 9 yang merupakan tampilan dari transaksi barter.

\section{Transaksi Barter Masuk}

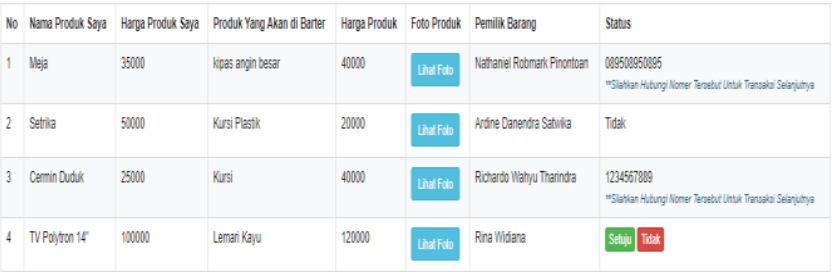

Gambar. 9. Detail Transaksi Barter

3. Penerapan Pengujian Sistem

TABEL I

TABEL TUGAS MEMBER SEBAGAI PEMBELI

\begin{tabular}{|c|l|}
\hline No & \multicolumn{1}{|c|}{ Tugas yang Dikerjakan } \\
\hline A & $\begin{array}{l}\text { Member login dengan akun yang sudah } \\
\text { terdaftar }\end{array}$ \\
\hline B & $\begin{array}{l}\text { Melakukan pencarian produk meja, jenis } \\
\text { produk satuan, kabupaten Yogyakarta }\end{array}$ \\
\hline C & Melakukan pembelian produk meja \\
\hline D & Mengirim bukti transfer \\
\hline E & Melakukan validasi produk telah diterima \\
\hline F & Melakukan pencarian jenis produk barter \\
\hline G & Melakukan transaksi barter \\
\hline
\end{tabular}

TABEL II

TABEL TUGAS MEMBER SEBAGAI PENJUAL

\begin{tabular}{|c|l|}
\hline No & \multicolumn{1}{|c|}{ Tugas yang Dikerjakan } \\
\hline A & Menjual produk \\
\hline B & Melihat produk menunggu validasi \\
\hline C & Mengubah data produk \\
\hline D & Melakukan validasi bukti transfer \\
\hline E & Mengirim resi pengiriman \\
\hline F & Melakukan validasi transaksi barter \\
\hline
\end{tabular}

\section{B. Hasil Testing}

Responden yang terlibat dalam usability testing ini berjumlah 22 orang. Testing yang digunakan adalah formative testing yang mempunya arti melakukan pengujian dengan tujuan untuk dilakukan perbaikan. Responden ratarata merupakan mahasiswa dan orang umum yang bisa mengoperasikan komputer dan biasa melakukan jual beli online.
Pengujian dengan parameter yang pertama adalah success rate yang bertujuan untuk mengetahui sejauh mana responden berhasil menyelesaikan tugas yang telah diberikan. Nilai 1 menunjukkan responden berhasil menyelesaikan tugas dan nilai 0 menunjukkan responden tidak berhasil menyelesaikan tugas.

Pengujian dengan parameter yang kedua adalah error rate yang bertujuan untuk menghitung berapa kali jumlah kesalahan atau error yang terjadi saat responden melaksanakan tugas yang diberikan. Nilai 0 menunjukkan bahwa tugas yang diberikan tidak terjadi kesalahan atau error. Nilai 1 menunjukkan terdapat kesalahan atau error saat melaksanakan tugas yang diberikan.

Pengujian dengan parameter yang ketiga adalah User's subjective satisfaction yang bertujuan untuk menghitung rating yang diberikan oleh responden pada tugas yang diberikan. Rentang rating yang diberikan yaitu bernilai 1-5 dengan nilai 1 buruk, 2 kurang, 3 cukup, 4 baik, 5 sangat baik.

TABEL III

TABEL SUCCESS RATE MEMBER SEBAGAI PEMBELI

\begin{tabular}{|l|l|l|l|l|l|l|l|l|c|}
\hline No & Nama & A & B & C & D & E & F & G & Persentase \\
\hline 1 & Albert & 1 & 1 & 1 & 1 & 1 & 1 & 1 & $100 \%$ \\
\hline 2 & Ardine & 1 & 1 & 1 & 1 & 1 & 1 & 1 & $100 \%$ \\
\hline 3 & Rina & 1 & 1 & 1 & 1 & 1 & 1 & 1 & $100 \%$ \\
\hline 4 & Ardo & 1 & 1 & 1 & 1 & 1 & 1 & 1 & $100 \%$ \\
\hline 5 & Sherly & 1 & 1 & 1 & 1 & 1 & 1 & 1 & $100 \%$ \\
\hline 6 & Valdo & 1 & 1 & 1 & 1 & 1 & 1 & 1 & $100 \%$ \\
\hline 7 & Stevani & 1 & 1 & 1 & 1 & 1 & 1 & 1 & $100 \%$ \\
\hline 8 & Nathan & 1 & 1 & 1 & 1 & 1 & 1 & 1 & $100 \%$ \\
\hline 9 & Richard & 1 & 1 & 1 & 1 & 1 & 1 & 1 & $100 \%$ \\
\hline 10 & Rivaldo & 1 & 1 & 1 & 1 & 1 & 1 & 1 & $100 \%$ \\
\hline 11 & Madya & 1 & 1 & 1 & 1 & 1 & 1 & 1 & $100 \%$ \\
\hline 12 & Satno & 1 & 1 & 1 & 1 & 1 & 1 & 1 & $100 \%$ \\
\hline 13 & Widi & 1 & 1 & 1 & 1 & 1 & 1 & 1 & $100 \%$ \\
\hline 14 & Ichi & 1 & 1 & 1 & 1 & 1 & 1 & 1 & $100 \%$ \\
\hline 15 & Reiner & 1 & 1 & 1 & 1 & 1 & 1 & 1 & $100 \%$ \\
\hline 16 & Frendy & 1 & 1 & 1 & 1 & 1 & 1 & 1 & $100 \%$ \\
\hline 17 & Narko & 1 & 1 & 1 & 1 & 1 & 1 & 1 & $100 \%$ \\
\hline 18 & Tius & 1 & 1 & 1 & 1 & 1 & 1 & 1 & $100 \%$ \\
\hline 19 & Hendra & 1 & 1 & 1 & 1 & 1 & 1 & 1 & $100 \%$ \\
\hline 20 & Linda & 1 & 1 & 1 & 1 & 1 & 1 & 1 & $100 \%$ \\
\hline 21 & Irine & 1 & 1 & 1 & 1 & 1 & 1 & 1 & $100 \%$ \\
\hline 22 & Ari & 1 & 1 & 1 & 1 & 1 & 1 & 1 & $100 \%$ \\
\hline
\end{tabular}

TABEL IV

TABEL ERROR RATE MEMBER SEBAGAI PEMBELI

\begin{tabular}{|l|l|l|l|l|l|l|l|l|c|}
\hline No & Nama & A & B & C & D & E & F & G & Jumlah \\
\hline 1 & Albert & 0 & 0 & 0 & 0 & 0 & 0 & 0 & 0 \\
\hline 2 & Ardine & 0 & 0 & 0 & 1 & 0 & 0 & 0 & 1 \\
\hline 3 & Rina & 0 & 0 & 0 & 1 & 0 & 0 & 0 & 1 \\
\hline 4 & Ardo & 0 & 0 & 0 & 0 & 0 & 0 & 0 & 0 \\
\hline 5 & Sherly & 0 & 0 & 0 & 0 & 0 & 0 & 0 & 0 \\
\hline 6 & Valdo & 0 & 0 & 0 & 0 & 0 & 0 & 0 & 0 \\
\hline 7 & Stevani & 0 & 0 & 0 & 0 & 0 & 1 & 0 & 1 \\
\hline 8 & Nathan & 0 & 0 & 0 & 0 & 0 & 0 & 0 & 0 \\
\hline 9 & Richard & 0 & 0 & 0 & 0 & 0 & 0 & 0 & 0 \\
\hline 10 & Rivaldo & 0 & 0 & 0 & 1 & 0 & 0 & 0 & 1 \\
\hline 11 & Madya & 0 & 0 & 0 & 1 & 0 & 0 & 0 & 1 \\
\hline 12 & Satno & 0 & 0 & 0 & 0 & 0 & 0 & 0 & 0 \\
\hline 13 & Widi & 0 & 0 & 0 & 0 & 1 & 0 & 0 & 1 \\
\hline 14 & Ichi & 0 & 0 & 0 & 0 & 0 & 1 & 0 & 1 \\
\hline 15 & Reiner & 0 & 0 & 0 & 1 & 0 & 0 & 0 & 1 \\
\hline
\end{tabular}




\begin{tabular}{|c|c|c|c|c|c|c|c|c|c|}
\hline 16 & Frendy & 0 & 0 & 0 & 1 & 0 & 0 & 0 & 1 \\
\hline 17 & Narko & 0 & 0 & 0 & 1 & 1 & 0 & 0 & 2 \\
\hline 18 & Tius & 0 & 0 & 0 & 1 & 1 & 0 & 0 & 2 \\
\hline 19 & Hendra & 0 & 0 & 0 & 1 & 0 & 0 & 0 & 1 \\
\hline 20 & Linda & 0 & 0 & 0 & 1 & 0 & 0 & 0 & 1 \\
\hline 21 & Irine & 0 & 0 & 0 & 1 & 0 & 0 & 0 & 1 \\
\hline 22 & Ari & 0 & 0 & 0 & 0 & 0 & 0 & 0 & 0 \\
\hline \multicolumn{2}{|c|}{ Jumlah } & 0 & 0 & 0 & 11 & 3 & 2 & 0 & \\
\hline
\end{tabular}

TABEL V

TABEL RATING MEMBER SEBAGAI PEMBELI

\begin{tabular}{|l|l|l|l|l|l|l|l|l|c|}
\hline No & Nama & A & B & C & D & E & F & G & Rata-rata \\
\hline 1 & Albert & 4 & 5 & 4 & 5 & 4 & 5 & 5 & 4,6 \\
\hline 2 & Ardine & 5 & 4 & 5 & 3 & 4 & 5 & 3 & 4,1 \\
\hline 3 & Rina & 5 & 4 & 3 & 4 & 4 & 5 & 3 & 4 \\
\hline 4 & Ardo & 5 & 5 & 4 & 5 & 5 & 5 & 1 & 4,3 \\
\hline 5 & Sherly & 4 & 4 & 4 & 3 & 4 & 4 & 4 & 3,9 \\
\hline 6 & Valdo & 5 & 5 & 3 & 4 & 5 & 5 & 4 & 4,4 \\
\hline 7 & Stevani & 4 & 5 & 4 & 5 & 5 & 3 & 3 & 4,1 \\
\hline 8 & Nathan & 3 & 4 & 3 & 4 & 5 & 3 & 2 & 3,4 \\
\hline 9 & Richard & 4 & 4 & 5 & 5 & 5 & 4 & 4 & 4,4 \\
\hline 10 & Rivaldo & 4 & 5 & 4 & 5 & 5 & 4 & 5 & 4,6 \\
\hline 11 & Madya & 5 & 4 & 4 & 5 & 5 & 5 & 4 & 4,6 \\
\hline 12 & Satno & 4 & 3 & 3 & 4 & 4 & 5 & 5 & 4 \\
\hline 13 & Widi & 5 & 4 & 4 & 5 & 5 & 4 & 5 & 4,6 \\
\hline 14 & Ichi & 4 & 5 & 4 & 4 & 5 & 5 & 5 & 4,6 \\
\hline 15 & Reiner & 5 & 4 & 4 & 5 & 5 & 5 & 4 & 4,6 \\
\hline 16 & Frendy & 5 & 4 & 4 & 5 & 5 & 4 & 4 & 4,4 \\
\hline 17 & Narko & 5 & 5 & 4 & 4 & 5 & 4 & 4 & 4,4 \\
\hline 18 & Tius & 4 & 4 & 5 & 5 & 3 & 4 & 5 & 4,3 \\
\hline 19 & Hendra & 5 & 4 & 4 & 3 & 4 & 5 & 5 & 4,3 \\
\hline 20 & Linda & 5 & 4 & 4 & 4 & 4 & 4 & 5 & 4,3 \\
\hline 21 & Irine & 5 & 4 & 4 & 3 & 4 & 5 & 4 & 4,1 \\
\hline 22 & Ari & 5 & 4 & 4 & 4 & 4 & 5 & 4 & 4,3 \\
\hline
\end{tabular}

\section{C.Hasil Analisis Error Rate Member Sebagai Pembeli}

Berikut adalah analisis dari parameter error member sebagai pembeli. Berdasarkan data dari Tabel IV dengan jumlah responden sebanyak 22 , berikut perbandingan antara responden yang menyelesaikan task tanpa error dan dengan error. Sebesar $36 \%$ persen untuk responden yang dapat menyelesaikan task tanpa error, sedangkan sisanya sebesar 64\% dapat menyelesaikan task dengan error. Dari 7 Task yang diberikan, paling banyak terjadi error adalah pada bagian kirim bukti transfer sebanyak 11 responden, validasi pesanan diterima 3 responden, dan cari produk barter 2 responden.

TABEL VI

TABEL SUCCESS RATE SEBAGAI PENJUAL

\begin{tabular}{|l|l|l|l|l|l|l|l|c|}
\hline No & Nama & A & B & C & D & E & F & Persentase \\
\hline 1 & Albert & 1 & 1 & 1 & 1 & 1 & 1 & $100 \%$ \\
\hline 2 & Ardine & 1 & 1 & 1 & 0 & 1 & 1 & $83 \%$ \\
\hline 3 & Rina & 1 & 1 & 1 & 1 & 1 & 1 & $100 \%$ \\
\hline 4 & Ardo & 0 & 1 & 1 & 1 & 1 & 1 & $83 \%$ \\
\hline 5 & Sherly & 1 & 1 & 1 & 1 & 1 & 1 & $100 \%$ \\
\hline 6 & Valdo & 1 & 1 & 1 & 1 & 1 & 1 & $100 \%$ \\
\hline 7 & Stevani & 1 & 1 & 1 & 1 & 1 & 1 & $100 \%$ \\
\hline 8 & Nathan & 1 & 1 & 1 & 1 & 1 & 1 & $100 \%$ \\
\hline 9 & Richard & 1 & 1 & 1 & 1 & 1 & 1 & $100 \%$ \\
\hline 10 & Rivaldo & 1 & 1 & 1 & 1 & 1 & 1 & $100 \%$ \\
\hline 11 & Madya & 1 & 1 & 1 & 1 & 1 & 1 & $100 \%$ \\
\hline 12 & Satno & 1 & 1 & 1 & 1 & 1 & 1 & $100 \%$ \\
\hline 13 & Widi & 1 & 1 & 1 & 1 & 1 & 1 & $100 \%$ \\
\hline 14 & Ichi & 1 & 1 & 1 & 1 & 1 & 1 & $100 \%$ \\
\hline
\end{tabular}

\begin{tabular}{|l|l|l|l|l|l|l|l|l|}
\hline 15 & Reiner & 1 & 1 & 1 & 1 & 1 & 1 & $100 \%$ \\
\hline 16 & Frendy & 1 & 1 & 1 & 1 & 1 & 1 & $100 \%$ \\
\hline 17 & Narko & 1 & 1 & 1 & 1 & 1 & 1 & $100 \%$ \\
\hline 18 & Tius & 1 & 1 & 1 & 1 & 1 & 1 & $100 \%$ \\
\hline 19 & Hendra & 1 & 1 & 1 & 1 & 1 & 1 & $100 \%$ \\
\hline 20 & Linda & 1 & 1 & 1 & 1 & 1 & 1 & $100 \%$ \\
\hline 21 & Irine & 1 & 1 & 1 & 1 & 1 & 1 & $100 \%$ \\
\hline 22 & Ari & 1 & 1 & 1 & 1 & 1 & 1 & $100 \%$ \\
\hline
\end{tabular}

TABEL VII

TABEL ERROR RATE MEMBER SEBAGAI PENJUAL

\begin{tabular}{|l|l|l|l|l|l|l|l|c|}
\hline No & Nama & A & B & C & D & E & F & Jumlah \\
\hline 1 & Albert & 1 & 0 & 1 & 1 & 0 & 0 & 3 \\
\hline 2 & Ardine & 0 & 0 & 0 & 1 & 0 & 0 & 1 \\
\hline 3 & Rina & 0 & 1 & 0 & 1 & 0 & 0 & 2 \\
\hline 4 & Ardo & 1 & 0 & 0 & 0 & 0 & 0 & 1 \\
\hline 5 & Sherly & 0 & 0 & 0 & 0 & 0 & 0 & 0 \\
\hline 6 & Valdo & 1 & 0 & 0 & 0 & 0 & 0 & 1 \\
\hline 7 & Stevani & 0 & 0 & 0 & 0 & 0 & 0 & 0 \\
\hline 8 & Nathan & 0 & 0 & 0 & 0 & 0 & 0 & 0 \\
\hline 9 & Richard & 0 & 0 & 0 & 1 & 0 & 0 & 1 \\
\hline 10 & Rivaldo & 0 & 0 & 0 & 1 & 0 & 0 & 1 \\
\hline 11 & Madya & 0 & 0 & 0 & 1 & 0 & 0 & 1 \\
\hline 12 & Satno & 0 & 0 & 0 & 0 & 0 & 0 & 0 \\
\hline 13 & Widi & 0 & 0 & 0 & 0 & 0 & 0 & 0 \\
\hline 14 & Ichi & 0 & 0 & 0 & 0 & 0 & 0 & 0 \\
\hline 15 & Reiner & 0 & 0 & 0 & 0 & 0 & 0 & 0 \\
\hline 16 & Frendy & 0 & 0 & 0 & 1 & 0 & 1 & 2 \\
\hline 17 & Narko & 0 & 0 & 0 & 1 & 0 & 0 & 1 \\
\hline 18 & Tius & 1 & 0 & 0 & 1 & 0 & 0 & 2 \\
\hline 19 & Hendra & 0 & 0 & 0 & 1 & 0 & 0 & 1 \\
\hline 20 & Linda & 0 & 0 & 0 & 1 & 0 & 0 & 1 \\
\hline 21 & Irine & 0 & 0 & 0 & 1 & 0 & 0 & 1 \\
\hline 22 & Ari & 0 & 0 & 0 & 1 & 0 & 0 & 1 \\
\hline & Jumlah & 4 & 1 & 1 & 13 & 0 & 1 & \\
\hline
\end{tabular}

\section{D.Hasil Analsisis Error Rate Member Sebagai Penjual}

Pada bagian error member sebagai penjual, berdasarkan data dari Tabel VII perbandingan antara responden yang menyelesaikan task tanpa error dan dengan error. Sebesar $32 \%$ persen untuk responden yang dapat menyelesaikan task tanpa error, sedangkan sisanya sebesar 68\% dapat menyelesaikan task dengan error. Dari 6 task yang diberikan, task yang paling banyak terjadi error adalah validasi bukti transfer sebanyak 13 responden, jual barang dengan 4 responden, lihat produk menunggu validasi 1 responden, ubah data produk 1 reponden, validasi transaksi barter 1 responden.

Dari analisis yang telah dilakukan dapat disimpulkan bahwa error sering terjadi pada bagian task transfer.

TABEL VIII

TABEL RATING MEMBER SEBAGAI PENJUAL

\begin{tabular}{|l|l|l|l|l|l|l|l|c|}
\hline No & Nama & A & B & C & D & E & F & Rata-rata \\
\hline 1 & Albert & 4 & 4 & 5 & 5 & 5 & 4 & 4,5 \\
\hline 2 & Ardine & 3 & 4 & 5 & 2 & 4 & 5 & 3,8 \\
\hline 3 & Rina & 3 & 4 & 5 & 3 & 5 & 3 & 3,8 \\
\hline 4 & Ardo & 1 & 5 & 5 & 1 & 5 & 5 & 3,7 \\
\hline 5 & Sherly & 4 & 4 & 4 & 4 & 4 & 5 & 4,2 \\
\hline 6 & Valdo & 3 & 5 & 4 & 4 & 5 & 5 & 4,3 \\
\hline 7 & Stevani & 5 & 5 & 5 & 3 & 5 & 5 & 4,7 \\
\hline 8 & Nathan & 3 & 4 & 4 & 4 & 5 & 4 & 4 \\
\hline 9 & Richard & 4 & 4 & 5 & 5 & 5 & 5 & 4,7 \\
\hline 10 & Rivaldo & 4 & 5 & 5 & 4 & 4 & 5 & 4,5 \\
\hline
\end{tabular}




\begin{tabular}{|c|l|c|c|c|c|c|c|c|}
\hline 11 & Madya & 5 & 5 & 4 & 5 & 5 & 4 & 4,7 \\
\hline 12 & Satno & 4 & 5 & 5 & 4 & 4 & 5 & 4,5 \\
\hline 13 & Widi & 4 & 4 & 5 & 4 & 5 & 4 & 4,3 \\
\hline 14 & Ichi & 3 & 3 & 4 & 4 & 5 & 5 & 4 \\
\hline 15 & Reiner & 5 & 4 & 5 & 3 & 4 & 5 & 4,3 \\
\hline 16 & Frendy & 5 & 4 & 5 & 4 & 4 & 5 & 4,5 \\
\hline 17 & Narko & 4 & 4 & 5 & 4 & 5 & 4 & 4,3 \\
\hline 18 & Tius & 3 & 4 & 5 & 4 & 5 & 5 & 4,3 \\
\hline 19 & Hendra & 5 & 5 & 4 & 4 & 5 & 5 & 4,7 \\
\hline 20 & Linda & 5 & 5 & 5 & 4 & 4 & 5 & 4,7 \\
\hline 21 & Irine & 4 & 4 & 4 & 3 & 4 & 5 & 4 \\
\hline 22 & Ari & 4 & 5 & 5 & 4 & 4 & 5 & 4,5 \\
\hline
\end{tabular}

\section{E. Hasil Kombinasi dan Analisis}

Hasil usability testing menggunakan combining metrics based on percentages dengan hasil kombinasi dari dua parameter yang telah dipakai yaitu success rate dan User's subjective satisfaction. Pada Tabel IX merupakan hasil dari combining metrics based on percentages member sebagai pembeli dan Tabel $\mathrm{X}$ merupakan hasil dari combining metrics based on percentages member sebagai penjual.

TABEL IX

HASIL KOMBINASI MEMBER SEBAGAI PEMBELI

\begin{tabular}{|c|l|c|c|c|c|c|}
\hline No & Nama & $\begin{array}{c}\text { Task } \\
\text { Completed } \\
\text { (of 7) }\end{array}$ & $\begin{array}{c}\text { Rat- } \\
\text { ing }\end{array}$ & Task & $\begin{array}{c}\text { Satis- } \\
\text { faction }\end{array}$ & $\begin{array}{c}\text { Aver- } \\
\text { age }\end{array}$ \\
\hline 1 & Alberth & 7 & 4,6 & $100 \%$ & $92 \%$ & $96 \%$ \\
\hline 2 & Ardine & 7 & 4,1 & $100 \%$ & $82 \%$ & $91 \%$ \\
\hline 3 & Rina & 7 & 4 & $100 \%$ & $80 \%$ & $90 \%$ \\
\hline 4 & Ardo & 7 & 4,3 & $100 \%$ & $86 \%$ & $93 \%$ \\
\hline 5 & Sherly & 7 & 3,9 & $100 \%$ & $78 \%$ & $89 \%$ \\
\hline 6 & Valdo & 7 & 4,4 & $100 \%$ & $88 \%$ & $94 \%$ \\
\hline 7 & Stevani & 7 & 4,1 & $100 \%$ & $82 \%$ & $91 \%$ \\
\hline 8 & Nathan & 7 & 3,4 & $100 \%$ & $68 \%$ & $84 \%$ \\
\hline 9 & Richard & 7 & 4,4 & $100 \%$ & $88 \%$ & $94 \%$ \\
\hline 10 & Rivaldo & 7 & 4,6 & $100 \%$ & $92 \%$ & $96 \%$ \\
\hline 11 & Madya & 7 & 4,6 & $100 \%$ & $92 \%$ & $96 \%$ \\
\hline 12 & Satno & 7 & 4 & $100 \%$ & $80 \%$ & $90 \%$ \\
\hline 13 & Widi & 7 & 4,6 & $100 \%$ & $92 \%$ & $96 \%$ \\
\hline 14 & Ichi & 7 & 4,6 & $100 \%$ & $92 \%$ & $96 \%$ \\
\hline 15 & Reiner & 7 & 4,6 & $100 \%$ & $92 \%$ & $96 \%$ \\
\hline 16 & Frendy & 7 & 4,4 & $100 \%$ & $88 \%$ & $94 \%$ \\
\hline 17 & Narko & 7 & 4,4 & $100 \%$ & $88 \%$ & $94 \%$ \\
\hline 18 & Tius & 7 & 4,3 & $100 \%$ & $86 \%$ & $93 \%$ \\
\hline 19 & Hendra & 7 & 4,3 & $100 \%$ & $86 \%$ & $93 \%$ \\
\hline 20 & Linda & 7 & 4,3 & $100 \%$ & $86 \%$ & $93 \%$ \\
\hline 21 & Irine & 7 & 4,1 & $100 \%$ & $82 \%$ & $91 \%$ \\
\hline 22 & Ari & 7 & 4,3 & $100 \%$ & $86 \%$ & $93 \%$ \\
\hline
\end{tabular}

Pada Tabel IX merupakan hasil dari perhitungan kombinasi member sebagai pembeli. Persentase member dalam menyelesaikan 7 task yang diberikan mencapai 100\%, artinya semua responden berhasil menyelesaikan semua task yang diberikan dengan benar. Parameter kedua yaitu satisfaction rating yang berasal dari hasil rata-rata rating setiap responden yang digabung menjadi satu untuk mendapatkan hasil persentase satisfaction rating seluruh responden. Hasil persentase satisfaction rating seluruh responden saat menggunakan sistem sebesar $86 \%$. Pada hasil kombinasi untuk bagian task seluruh responden yang berjumlah 22 orang mencapai nilai $100 \%$, artinya seluruh responden berhasil menyelesaikan semua task yang diberikan. Sementara untuk hasil kombinasi satisfaction responden, rata-rata persentase sebesar 86\%. Hasil perhitungan persentase untuk rata-rata setelah dikombinasi

JUTEI Edisi Volume.4 No.1 April 2020

ISSN 2579-3675, e-ISSN 2579-5538

DOI 10.21460/jutei.2020.14.192 sebesar $93 \%$ artinya dapat dikatakan nilai usability testing yang dilakukan cukup baik.

TABEL X

HASIL KOMBINASI MEMBER SEBAGAI PENJUAL

\begin{tabular}{|c|l|c|c|c|c|c|}
\hline No & Nama & $\begin{array}{c}\text { Task } \\
\text { Completed } \\
\text { (Of 6) }\end{array}$ & $\begin{array}{c}\text { Rat- } \\
\text { ing }\end{array}$ & Task & $\begin{array}{c}\text { Satis- } \\
\text { faction }\end{array}$ & $\begin{array}{c}\text { Aver- } \\
\text { age }\end{array}$ \\
\hline 1 & Alberth & 6 & 4,5 & $100 \%$ & $90 \%$ & $95 \%$ \\
\hline 2 & Ardine & 5 & 3,8 & $83 \%$ & $76 \%$ & $80 \%$ \\
\hline 3 & Rina & 6 & 3,8 & $100 \%$ & $76 \%$ & $88 \%$ \\
\hline 4 & Ardo & 5 & 3,7 & $83 \%$ & $74 \%$ & $79 \%$ \\
\hline 5 & Sherly & 6 & 4,2 & $100 \%$ & $84 \%$ & $92 \%$ \\
\hline 6 & Valdo & 6 & 4,3 & $100 \%$ & $86 \%$ & $93 \%$ \\
\hline 7 & Stevani & 6 & 4,7 & $100 \%$ & $94 \%$ & $97 \%$ \\
\hline 8 & Nathan & 6 & 4 & $100 \%$ & $80 \%$ & $90 \%$ \\
\hline 9 & Richard & 6 & 4,7 & $100 \%$ & $94 \%$ & $97 \%$ \\
\hline 10 & Rivaldo & 6 & 4,5 & $100 \%$ & $90 \%$ & $95 \%$ \\
\hline 11 & Madya & 6 & 4,7 & $100 \%$ & $94 \%$ & $97 \%$ \\
\hline 12 & Satno & 6 & 4,5 & $100 \%$ & $90 \%$ & $95 \%$ \\
\hline 13 & Widi & 6 & 4,3 & $100 \%$ & $86 \%$ & $93 \%$ \\
\hline 14 & Ichi & 6 & 4 & $100 \%$ & $80 \%$ & $90 \%$ \\
\hline 15 & Reiner & 6 & 4,3 & $100 \%$ & $86 \%$ & $93 \%$ \\
\hline 16 & Frendy & 6 & 4,5 & $100 \%$ & $90 \%$ & $95 \%$ \\
\hline 17 & Narko & 6 & 4,3 & $100 \%$ & $86 \%$ & $93 \%$ \\
\hline 18 & Tius & 6 & 4,3 & $100 \%$ & $86 \%$ & $93 \%$ \\
\hline 19 & Hendra & 6 & 4,7 & $100 \%$ & $94 \%$ & $97 \%$ \\
\hline 20 & Linda & 6 & 4,7 & $100 \%$ & $94 \%$ & $97 \%$ \\
\hline 21 & Irine & 6 & 4 & $100 \%$ & $80 \%$ & $90 \%$ \\
\hline 22 & Ari & 6 & 4,5 & $100 \%$ & $90 \%$ & $95 \%$ \\
\hline
\end{tabular}

Pada Tabel X merupakan hasil kombinasi member sebagai penjual. Dari jumlah 22 responden dalam menyelesaikan seluruh task yang berjumlah 6 , sebesar $91 \%$ responden berhasil menyelesaikan seluruh task dengan benar dan sisanya sebesar 9\% tidak mampu menyelesaikan seluruh task dengan benar. Parameter kedua yaitu satisfaction rating yang berasal dari hasil rata-rata rating setiap responden yang digabung menjadi satu. Hasil persentase satisfaction rating seluruh responden saat menggunakan sistem sebesar $86 \%$, artinya responden cukup puas saat menggunakan sistem. Pada hasil kombinasi dari jumlah total 22 responden dalam menyelesaikan seluruh task yang berjumlah 6, sebesar $91 \%$ responden berhasil menyelesaikan seluruh task dengan benar dan sisanya sebesar 9\% tidak mampu menyelesaikan seluruh task dengan benar. Sementara untuk hasil kombinasi satisfaction responden, rata-rata persentase sebesar $86 \%$. Hasil perhitungan persentase untuk rata-rata setelah dikombinasi sebesar $92 \%$ artinya dapat dikatakan nilai usability testing member sebagai penjual yang telah dilakukan cukup baik.

\section{F. Catatan Timbal Balik Responden}

Pada bagian ini akan menjelaskan feedback dari responden setelah melakukan testing. Hasil Feedback dibagi menjadi beberapa kategori sesuai dengan jenisnya. 
TABEL XI

FEEDBACK RESPONDEN

\begin{tabular}{|c|c|c|c|}
\hline Tulisan & Soft Control & Warna & Navigasi \\
\hline $\begin{array}{l}\text { Tulisan jual } \\
\text { barang } \\
\text { kurang } \\
\text { menonjol } \\
\text { (3) }\end{array}$ & $\begin{array}{l}\text { Tombol jual } \\
\text { barang sulit } \\
\text { ditemukan (3) }\end{array}$ & $\begin{array}{l}\text { Warna } \\
\text { tampilan } \\
\text { lebih } \\
\text { menarik (1) }\end{array}$ & $\begin{array}{l}\text { Menu } \\
\text { daftar } \\
\text { barter } \\
\text { kurang } \\
\text { jelas (1) }\end{array}$ \\
\hline \multirow[t]{6}{*}{$\begin{array}{l}\text { Tulisan di } \\
\text { menu akun } \\
\text { saya terlalu } \\
\text { kecil (6) }\end{array}$} & $\begin{array}{l}\text { Tombol aksi } \\
\text { kurang besar (8) }\end{array}$ & $\begin{array}{l}\text { Diberi warna } \\
\text { pada menu } \\
\text { yang sedang } \\
\text { dipilih (1) }\end{array}$ & $\begin{array}{l}\text { Form wajib } \\
\text { diisi diberi } \\
\text { tanda (1) }\end{array}$ \\
\hline & $\begin{array}{l}\text { Tampilan } \\
\text { header kurang } \\
\text { menarik (1) }\end{array}$ & $\begin{array}{l}\text { Garisnya } \\
\text { diberi warna } \\
\text { saat } \\
\text { menampilkan } \\
\text { produk (1) }\end{array}$ & $\begin{array}{l}\text { Menu di } \\
\text { profil } \\
\text { kurang } \\
\text { besar (1) }\end{array}$ \\
\hline & $\begin{array}{l}\text { Button yang } \\
\text { sedang dipilih } \\
\text { diberi pembeda } \\
\text { (1) }\end{array}$ & & $\begin{array}{l}\text { Tambahkan } \\
\text { notifikasi } \\
\text { saat terjadi } \\
\text { barter (2) }\end{array}$ \\
\hline & $\begin{array}{l}\text { Button jual } \\
\text { barang ditambah } \\
\text { di halaman } \\
\text { utama (1) }\end{array}$ & & \\
\hline & $\begin{array}{l}\text { Tambah tombol } \\
\text { di detail } \\
\text { penjualan untuk } \\
\text { cek bukti } \\
\text { transfer (2) }\end{array}$ & & \\
\hline & $\begin{array}{l}\text { Sidebar di menu } \\
\text { profil } \\
\text { membingungkan } \\
\text { (1) }\end{array}$ & & \\
\hline
\end{tabular}

Sebelum

Sesudah
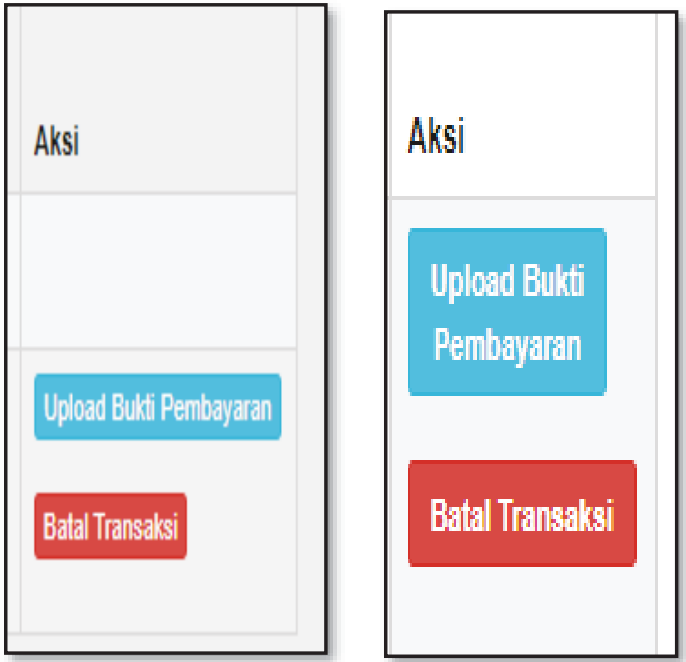

Gambar. 10. Tampilan Tombol Aksi Sebelum dan Sesudah
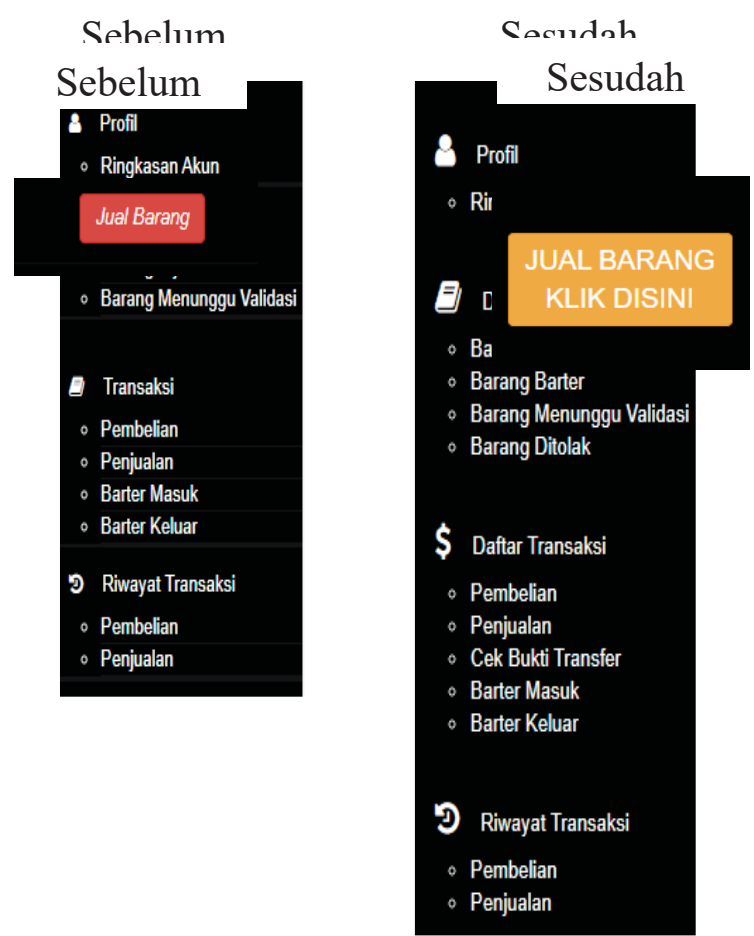

Gambar. 12. Tampilan Tulisan Jual Barang Sebelum dan Sesudah Pengujian

\section{G.Kelebihan dan Kekurangan Sistem}

Berikut merupakan beberapa kelebihan sistem yang telah dilakukan pengujian :

1. Sistem mampu menampilkan barang yang sedang dijual.

2. Sistem mampu melakukan pencarian barang yang dijual secara satuan, sepaket, dan barter.

3. Sistem mampu menjual atau membeli barang secara satuan atau langsung sepaket misalnya beberapa barang langsung seperti meja, kursi dan lemari.

4. Sistem mampu menghubungkan penjual dan pembeli yang akan melakukan transaksi barter.

Selain itu sistem juga memiliki beberapa kekurangan diantaranya :

1. Sistem tidak dapat membedakan penjual sehingga sistem hanya dapat melakukan pembelian satu barang pada satu penjual setiap transaksi.

2. Sistem belum mampu menampilan notifikasi ketika terjadi transaksi jual beli atau barter.

3. Sistem tidak dapat melakukan cancel otomatis saat pembeli melewati batas transfer.

4. Sistem belum mampu melakukan barter dari katalog daftar barang barter yang sudah dimiliki.

\section{V.KESIMPULAN DAN SARAN}

Berdasarkan hasil implementasi dan analisis dari sistem yang telah dibangun yaitu website jual beli barang bekas kos, maka dapat diambil kesimpulan sebagai berikut :

1. Website jual beli barang bekas kos mampu melakukan tranksaksi jual beli secara satuan atau langsung sepaket beberapa barang sekaligus. Selain itu pada website jual beli barang bekas kos juga 
dapat menghubungkan penjual dan pembeli yang ingin bertransaksi secara barter.

2. Untuk hasil pengujian usability, dilakukan perhitungan dengan menggunakan combining metrics based on percentages sehingga menghasilkan nilai usability sebesar 93\% untuk nilai member sebagai pembeli dan $92 \%$ perhitungan usability saat member sebagai penjual.

Saran untuk sistem website jual beli barang bekas kos adalah sebagai berikut :

1. Sistem dapat melakukan pembelian beberapa barang sekaligus kepada beberapa penjual yang berbeda dalam 1 kali transaksi.

2. Saat barter sistem bisa menawarkan barang barter dari katalog barang barter yang dimiliki.

3. Sistem dapat mengubah jenis barang yang awalnya satuan menjadi sepaket tanpa perlu menjual ulang barangnya.

4. Sistem dapat memberikan pemberitahuan saat ada pembelian.

\section{UCAPAN TERIMA KASIH}

Dalam penelitian tugas akhir ini, penulis mendapatkan bantuan, saran, bimbingan, dan dukungan dari berbagai pihak. Oleh karena itu, penulis ingin mengucapkan terima kasih pertama kepada Tuhan Yesus Kristus, kemudian kepada dosen pembimbing I dan II, teman-teman, serta pihak - pihak lain yang tidak dapat penulis sebutkan satu per satu yang berperan secara langsung maupun tidak langsung. Dalam penelitian ini, penulis menyadari bahwa masih ada kekurangan. Oleh karena itu, penulis sangat mengharapkan adanya kritik dan saran dari pembaca.

\section{DAFTAR PUSTAKA}

[1] D. J. K. \&. Dikti, "Ristekdikti," 4 April 2019. [Online]. Available: https://kelembagaan.ristekdikti.go.id/index.php/kopertis-wilayah-vd-i-yogyakarta/.

[2] C. Abras, D. Maloney-Krichmar dan J. Precee, "User-Centered Design," Encyclopedia of Human-Computer Interaction, vol. 37, pp. 445-446, 2004

[3] M. Magain, "What Does a User-Centred Design Process Look Like?," 12 February 2013. [Online]. Available: https://uxmastery.com/whatdoes-a-user-centred-design-process-look-like/.

[4] J. Nielsen, "Usability 101: Introduction to Usability," Usability 101: Introduction to Usability, 4 January 2012.

[5] M. D. Oelangan, "Akibat Hukum Bagi Pelaku Perjanjian Barter dalam Transaksi Perdagangan Eksport-Import di Indonesia,” Jurnal Pranata Hukum, vol. 2, pp. 139-145, 2007.

[6] Duniapcoid, "Barter Adalah: Pengertian, Sejarah, Jenis, Syarat, Kekurangan dan Kelebihan," 13 September 2019. [Online]. Available: https://duniapendidikan.co.id/barter-adalah-pengertiansejarah/.

[7] A. Y. Vadwala dan M. S.Vadwala, "E-Commerce :Merits and Demerits A Review Paper," International Journal of Trend in Scientific Research and Development, vol. 1, pp. 117-120, 2017.

[8] R. Yulianto, Francisca dan E. Pramana, "Pengujian Usability Untuk Meningkatkan Efektifitas Antarmuka Perangkat Lunak Pengenalan Huruf Dan Angka Untuk Siswa Taman Kanak-kanak," IdeaTech, pp. 282 - 289, 2015.

[9] S. M. Maulana, H. Susilo dan Riyadi, "Implementasi E-Commerce Sebagai Media Penjualan Online.," Jurnal Administrasi Bisnis, vol. 29, pp. 1-9, 2015.

JUTEI Edisi Volume.4 No.1 April 2020

ISSN 2579-3675, e-ISSN 2579-5538

DOI 10.21460/jutei.2020.14.192
[10] W. Widhiarso, Jessianti dan Sutini, "Metode UCD untuk Rancangan Kios Informasi Studi Kasus : Rumah Sakit Bersalin XYZ," Jurnal Ilmiah STIMIK GI MDP, vol. 3, pp. 6-10, 2007. 